\title{
Implementation of Self-Assessment on The Formative Test in Chemistry Using Feedback Clue
}

\author{
Wiwi Siswaningsih ${ }^{1^{*}}$, Budi Susetyo ${ }^{2}$, Zakiyah Pujiastuti ${ }^{3}$ \\ Department of Chemistry Education, Indonesian University of Education \\ Setiabudhi Street No. 229 Bandung 40154, Indonesia \\ *wiwi2450@gmail.com
}

\begin{tabular}{ll}
\hline Abstract \\
\hline Feywords: & This study aims to describe the compliance every stage of self-assessment \\
Feedback, & implementation of upper secondary school students on the topic of salt hydrolysis \\
Formative test, & formative test by using feedback instructions (clue), the ability of students to conduct \\
Salt hydrolysis, & self-assessment on the salt hydrolysis formative test by using feedback instructions, as \\
Self-assessment & well as the ability of self-assessment on the formative salt hydrolysis test to be used as \\
& feedback of upper secondary school students. This research was conducted by using a \\
descriptive method that involved 27 eleventh graders who took the Science program. & The research was conducted in six stages with different compliance in every stage. The \\
& compliance category of the students' motivation and self-assessment training stage was \\
& good, the implementation stage of a formative test using feedback instructions (clue) \\
& was good, the implementation stage of self-assessment was very good, the stage of \\
& communicating the results for feedback (ideal criteria implemented) was very good, and \\
& the stage of utilizing the results was very good. In the implementation of self- \\
& assessment, most students could carry out self-assessment well. Besides, it has also \\
known that students were satisfied with the feedback given by using the self-assessment & rubric and they got benefits in the form of feedback clue from the self-assessment rubric. \\
& This result showed that self-assessment helped educators in providing feedback to the \\
& student.
\end{tabular}

To cite this article:

Siswaningsih, W., Susetyo, B., Pujiastuti, Z. (2020). Implementation of Self-Assessment on The Formative Test in Chemistry Using Feedback Clue. Thabiea : Journal of Natural Science Teaching, 3(2), 120-130.

\section{Introduction}

The self-assessment was used as a technique in implementing formative test where students could reflect and evaluate the quality of their work and learning, assess the extent to which they reflect explicitly stated goals or criteria, and identify strengths and weaknesses in their work so they can improve them, therefore implementing a formative test using selfassessment techniques is very important (Wanner \& Palmer, 2018). The self-assessment can help encourage students to actively participate in monitoring the learning process independently, provide appropriate feedback, and improve students' abilities (Thawabieh A. M., 2017). In a study conducted by Bedford \& Legg (Bedford, S. \& Legg, S., 2007) selfassessment was considered very effective in providing feedback to students, in this case, students can learn from their own mistakes, therefore this study is expected to encourage students to evaluate their own abilities so that they can correct or develop for further learning and it is known from the feedback given on the implementation of the self-assessment. 
The formative test allows educators to be more understand the cognitive abilities of students' learning and allows students to find new methods for effective learning (Looney, A. et al., 2018). The formative test can be used as a tool to determine the success of the teaching and learning process carried out by educators, to obtain feedback on the progress that has been achieved (Orsmond, P. \& Merry, S., 2013). The self-assessment can be applied as an assessment tool in the implementation of the formative test to be used as feedback (Bedford, S. \& Legg, S., 2007). The questions on the formative test used Anderson and Krathwol's taxonomy at the C4 level (analyze). The formative test was given to students with two different question packages but both contain the same concept.

Giving feedback in the learning process is very important to support learning outcomes. This is in line with the statement, feedback could be used to measure students' progress in learning (Udoukpong, B. E \& Okon, C. P., 2012). However, based on the preliminary study conducted, educators could not always provide feedback to students and sometimes only provide remedial for students whose scores didn't get the standard, therefore the application of self-assessment on formative test using feedback instructions was expected to help students to get feedback so that they could learn their own mistake. In previous research (Yan, Z. et al., 2020), it was shown that students got better after implementing self-assessments and the same standard feedback instruction (clues).

The giving feedback could also in a different form such as the instructions in working on formative test questions called feedback clue. The feedback clue was designed for measuring the students' honesty level. The feedback clue was installed using a nylon cable tie, so when the students tried to opening the blue or red sheet, they must tearing it and the remaining feedback clues are not used. The remaining feedback clues were collected by the educators. It is necessary to make a sitting plan to observe students easier for educators. Besides, students are also required to fill out the self-assessment sheet by ticking the available column if using the blue or red sheet or both.

The reason for choosing the salt hydrolysis material was based on the Ministry of Education and Culture on the basic competency of 3.11 class XI students are expected to be able to master the material up to a high level of thinking. This material is very suitable if used self-assessment techniques because according to (Thawabieh A. M., 2017), the self-assessment technique can increase the motivation of students in developing higher-order thinking skills. The purpose of this study was to describe the achievement of each stage of implementation selfassessment of senior high school students on the formative test of salt hydrolysis using feedback clue, the ability of students to conduct self-assessment on the formative test of hydrolysis salt using feedback clue, as well as described self-assessment on the formative test of salt hydrolysis to be used feedback for senior high school students.

\section{Method}

This research was conducted by using a descriptive method that involved 27 eleventh graders who took the Science program in one of the public senior high schools in Bandung who had studied salt hydrolysis. The research process was started from the preparation stage including conducting a preliminary study, namely interviewing the chemistry's teacher, then carrying out literature that used salt hydrolysis to study based on the 2013 curriculum, and continued with analyzing the content (Siswaningsih, W. et al., 2013). Limited description 
questions and answer keys have been developed by previous researchers (Aeniah, R., 2012). The question indicators in this study include analyzing the properties of the salt solution using the hydrolysis concept and analyzing the $\mathrm{pH}$ value obtained from certain salt solutions. Moreover, the other research instruments on this research were made, such as feedback clue sheets in the form of blue and red sheets, self-assessment and rubrics sheets, interview guidelines, and questionnaire guidelines which have been validated by five validators. The data obtained from this study included the results of formative test assessments by students and researchers, questionnaires, and interviews, as well as the results of observations on the implementation of the six stages of implementing self-assessment. The results of the observations are used to describe each stage of the self-assessment application. The results of questionnaires and interviews are not only used to describe each stage of the application of the self-assessment but also to describe the ability of self-assessment on the formative salt hydrolysis test to be used as feedback. The results of the assessment of the formal tests carried out by students and researchers are used to describe the ability of students to carry out selfassessments. In analyzing the data on students 'abilities in carrying out self-assessments, first comparing the assessments made by students and researchers, then calculating the percentage of each student's ability based on the number of students' assessments that are the same as the researchers, then categorized. Next, calculate the percentage of the number of students for each category. Also, the results of student questionnaires need to be processed to determine the categories of each stage of the self-assessment application. The results of the validation of the instrument were revised to be performed in the research. Before implementing the research method, a pretest step was conducted to compare the results before and after using the formative test. At the implementation process, students follow all the stages of implementing selfassessment, start from the motivation stage to the utilization of the results. The data obtained were then analyzed and discussed to get conclusions of the research applied.

\section{Results and Discussion}

\section{The Achievement in each stage for implementation of self-assessment on the formative test in chemistry using feedback clue.}

The question indicators in this study include analyzing the properties of the salt solution using the hydrolysis concept and analyzing the $\mathrm{pH}$ value obtained from certain salt solutions. Students who use these feedback instructions get punishment, namely a reduced score. The instrument use of feedback clue refers to the states that feedback can also be given to students through instructions that can lead students to understand the learning material presented so that they are motivated to learn better (Orsmond, P. \& Merry, S., 2011).

There was another instrument in which the stages of implementing self-assessment modified by Siswaningsih (Siswaningsih, W. et al., 2013). The instrument was adapted from the application stage of the assessment according to Orsmond. The instrument includes the motivation stage of students, the self-assessment training stage, the implementation stage of the formative test using feedback clue, the implementation stage of self-assessment, the result communication stage for feedback, and the utilization stage of the result (Orsmond, P. \& Merry, S., 2013). According to Kusminto (Kusminto \& Joko, B. P., 2013), clear and objective assessment criteria need to be made before the implementation stage of the self-assessment is carried out. The criteria for proper self-assessment criteria for the achievement of each stage 
are described in the statement of Orsmond (Orsmond, P. \& Merry, S., 2011), which then goes on by Siswaningsih (Siswaningsih, W. et al., 2013) and applied on the implementation of formative tests. In this study, the stages of activities and the application of self-assessment were carried out in learning activities and carried out to students without using directions to see students' initial applications. This research was conducted after the material was fully presented. The time used in all stages of this self-assessment is 90 minutes (two hours of lessons) in one meeting. The details of the implementation time for the stages are 5 minutes for the motivation stage of students, 20 minutes for the self-assessment training stage, 20 minutes for the implementation stage of the formative test using feedback clue, 20 minutes for the implementation stage of self-assessment, 15 minutes for the result communication stage for feedback, and 10 minutes for the utilization stage of the result.

In the motivation stage, students are given information about the meaning, objectives, benefits, and advantages of self-assessment compared to other assessments. The purpose of this stage is to achieve an effective self-assessment so that it can provide optimal feedback to students. The achievement of the ideal criteria at the motivation stage of students' results are shown in Figure 1.

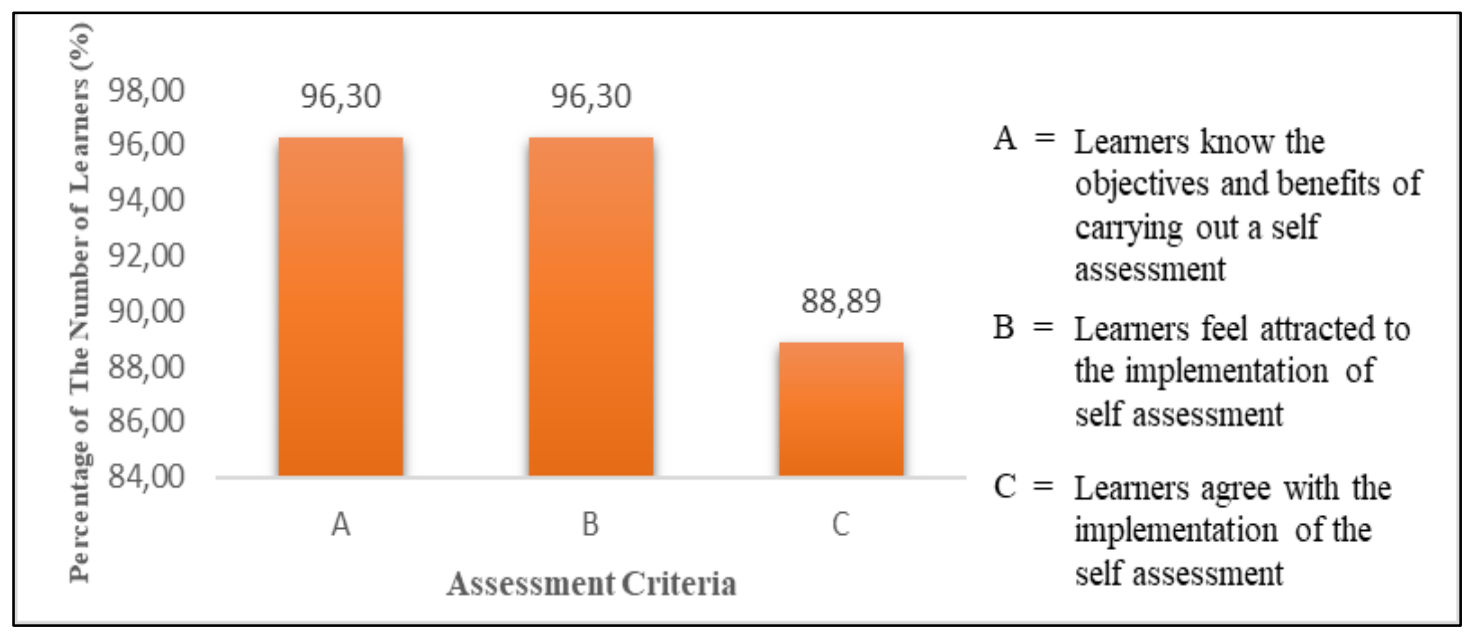

Figure 1. Percentage of Students Questionnaire and Interview Results from the Motivation Stage of Students

The average result of the achievement of the ideal criteria from the motivation stage of students is $93.83 \%$. According to Riduwan (Riduwan, 2010), the percentage of questionnaire data results and learner interviews from the three assessment criteria in the motivation stage is classified as very strong. Thus, it can be said the students know the objectives and benefits of implementing self-assessment, feel interested in implementing self-assessment, and agree with the implementation of self-assessment, or in other words, this stage is carried out very well. Students feel attracted to the implementation of self-assessment because based on the results of interviews, students think that self-assessment is a new assessment technique and has never been done before. This is also known because at the time of observation students gave good responses when asked questions related to this assessment technique. Students feel that they agree with the implementation of self-assessment because it provides many benefits for them. 
Students can also train honesty and self-confidence to improve the quality of their learning, as well as find out their own abilities and shortcomings in understanding salt hydrolysis material. However, some people do not agree with the implementation of self-assessments because according to them it is educators who should judge the results of their work, besides that there are students who feel increasingly insecure if they know the results of their own work. The selfassessment training stage is carried out for students to provide an explanation of the technical or procedure carried out at the time of the self-assessment. The achievement of the ideal criteria at the self-assessment training stage results are shown in Figure 2.

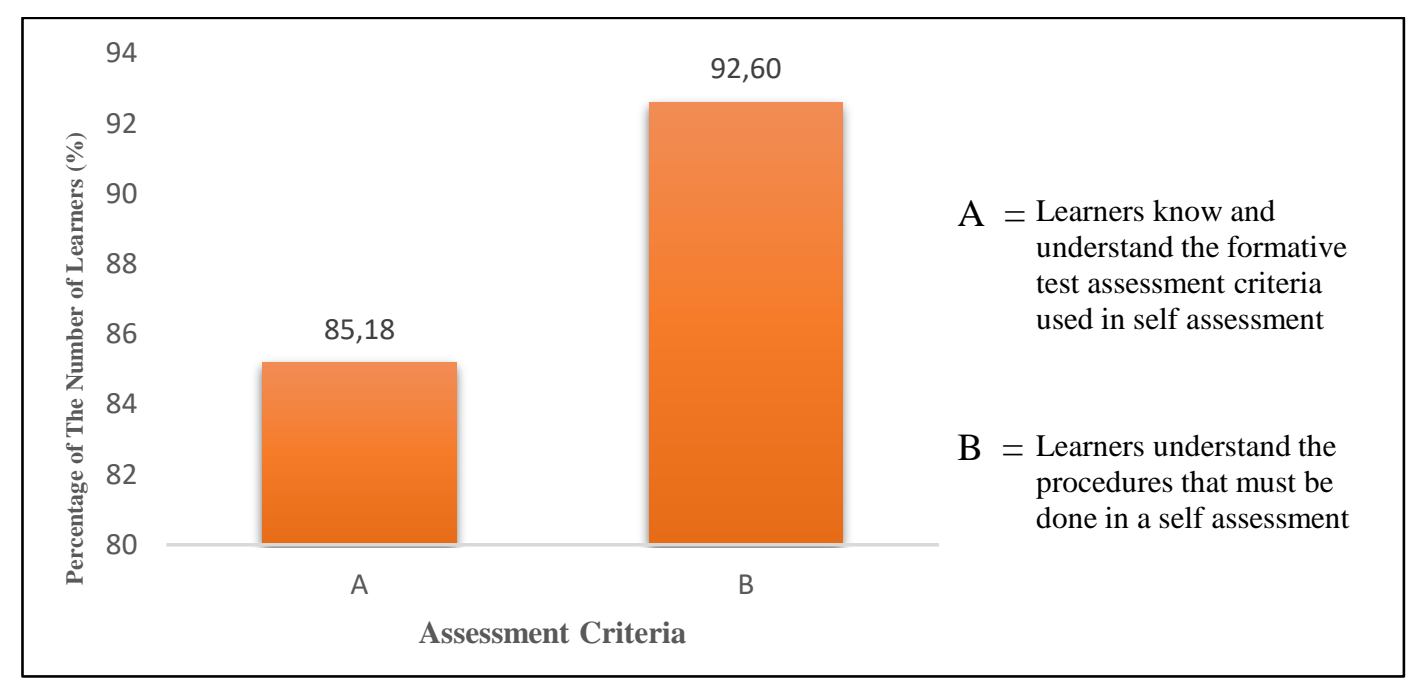

Figure 2. Percentage of Students Questionnaire Results from The Self-Assessment Stage

The average result of the achievement of the ideal criteria from the self-assessment training stage is $88.89 \%$. According to Riduwan (Riduwan, 2010), the percentage of learner questionnaire data results from the two assessment criteria in the self-assessment training stage is classified as very strong, or in other words, this stage is implemented very well. This can be seen at the time of observation, giving responses by answering questions related to the differences in scores obtained when using the blue feedback hint sheet, red feedback sheet, or without using the feedback hint sheet. Besides, it was seen that during the observation, students paid attention to the formative test simulations given and gave good responses. A small portion of students does not know the procedures and assessment criteria in the self-assessment. This is because students lack focus and paying less attention to formative test simulations using feedback clue and how to assess them.

The implementation stage of the formative test using feedback clue. Students are given two packages of different formative test questions in the form of limited descriptions which are done in 20 minutes. The use of description questions is very useful in developing the abilities of students. According to Arifin (Arifin, Z., 2017), description questions are used to measure the goals of achieving learning outcomes in complex aspects. The results of data processing regarding the achievement of the ideal criteria at the formative test implementation stage using feedback instructions are shown in Figure 3. 


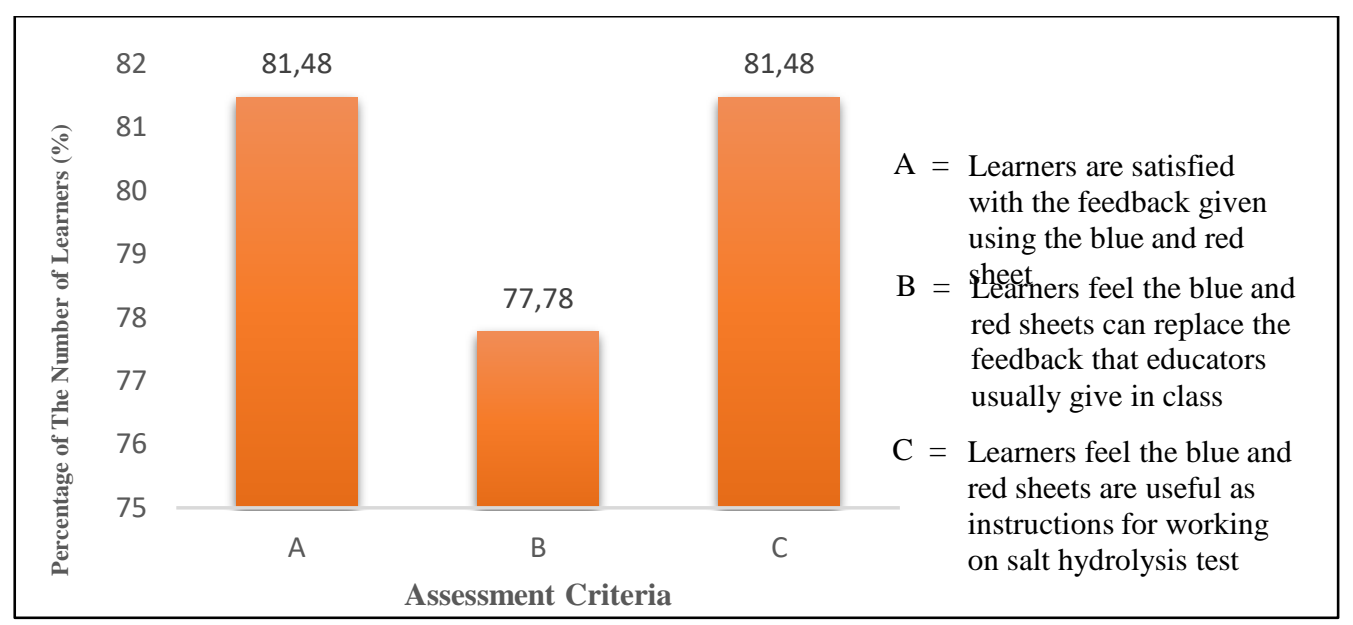

Figure 3. Percentage of Students Questionnaire and Interview Results from The Implementation Stage of The Formative Test Using Feedback

The average result of the achievement of the ideal criteria from the implementation stage of the formative test using feedback clue is $80.25 \%$. According to Riduwan (Riduwan, 2010), the percentage of questionnaire data results and learner interviews from the three assessment criteria in the implementation stage of formative tests using the feedback clue is classified as strong, or in other words, this stage is implemented well. This shows that students feel helped by the presence of feedback clue in the form of blue and red sheets. In the implementation of the formative test, as many as $81.48 \%$ of students used the feedback clue. Students feel satisfied and helped in solving salt hydrolysis formative test questions and are motivated to learn materials that are not yet understood. Even students think that the feedback clue can replace the usual feedback that educators give in class.

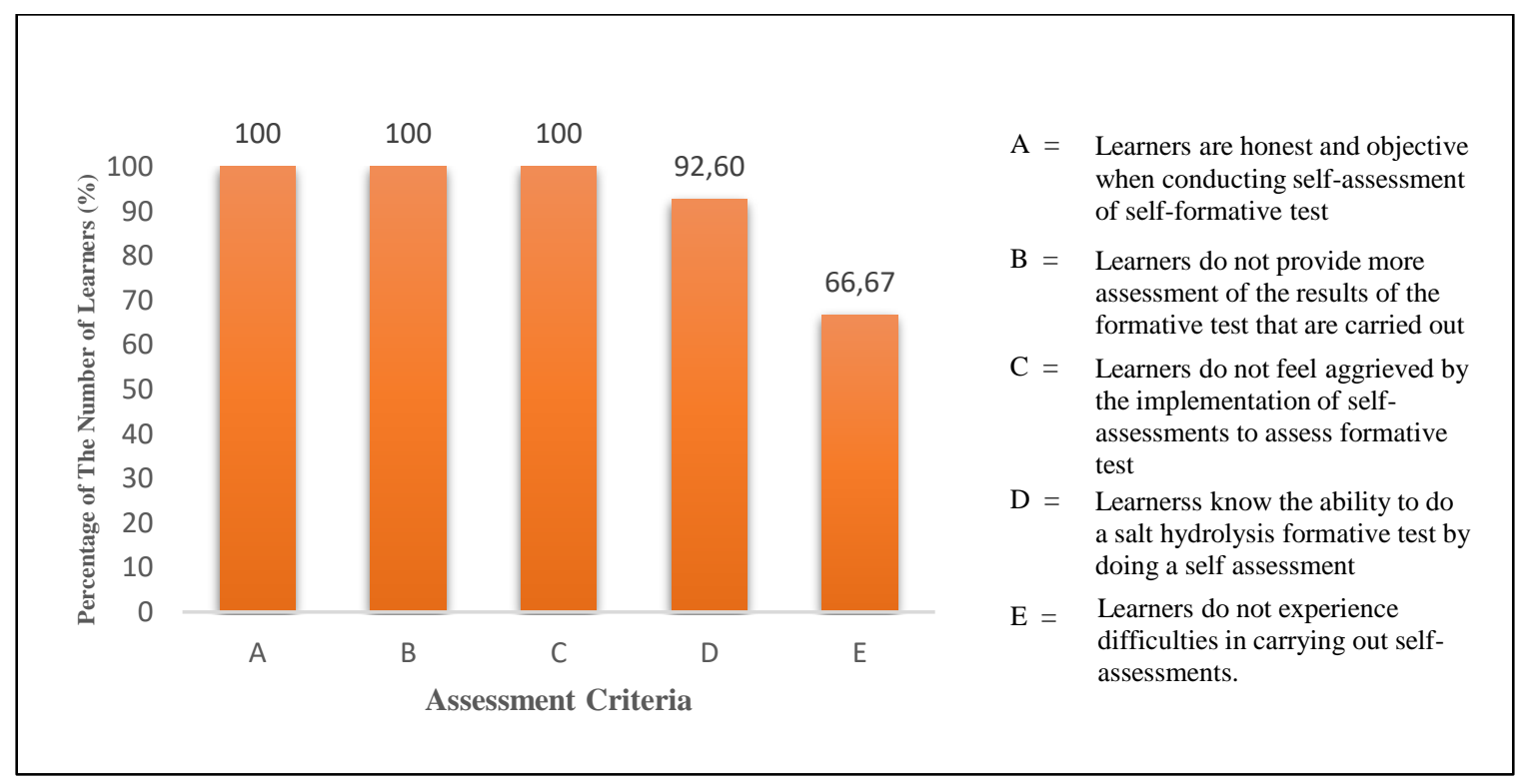

Figure 4. Percentage of Students Questionnaire and Interview Results from The Implementation Stage of Self-Assessment.

In the implementation stage of self-assessment, students assess the answers to the 
formative test of salt hydrolysis themselves by giving a score on the formative test answer sheet, so that after doing the formative test they immediately assess the results of their work. The results of data processing regarding the achievement of the ideal criteria at the self-assessment stage are shown in Figure 4.

The average result of the achievement of the five ideal criteria from the implementation stage of the self-assessment is $91.11 \%$. According to Riduwan (Riduwan, 2010), the percentage of questionnaire data results and learner interviews from the five assessment criteria in the implementation stage of self-assessment is classified as very strong, or in other words, this stage is carried out very well. This shows that students feel the benefits of implementing selfassessment. Students after going through this self-assessment stage are expected to be able to correct their mistakes and improve the quality of their learning in order to fully understand salt hydrolysis. The results of the observation showed that all students gave a check-list in the column using the feedback instruction sheet available on the answer sheet when they used the feedback instruction sheet. The amount of use of the feedback instruction sheet is in accordance with the data from the observations made by the researcher when examining the feedback instruction sheet used by students. At the time of observation, the researchers also did not find students who asked each other questions, they did formative tests independently. Based on the results of the interview, self-assessment provides significant benefits for students. The benefit obtained by students is that they can find out their abilities and shortcomings in understanding the salt hydrolysis material. The students do not know their ability to do salt hydrolysis formative test by conducting a self-assessment. It is because the students do not understand the salt hydrolysis material, so they still need an explanation of the material from the educator as a whole regarding the salt hydrolysis material. However, there are still students who find it difficult to carry out self-assessments. The difficulties faced by students are known when conducting interviews. The difficulties faced by students are due to the lack of understanding of students against the assessment criteria. Students feel confused in determining the score for the answers they write on the answer sheet because students are not used to assessing their own formative test answers using a self-assessment rubric. It is also known that at the time of the self-assessment, there were still students who asked the researchers regarding the scoring of the answers. The result communication stage for feedback has two ideal criteria, namely the results of the assessment are communicated orally and in writing to students. Communicating the results orally is conveyed directly by the researcher then the students respond directly so that a discussion process is formed from the results of the feedback submitted. The researcher communicates the results in writing through the students' answer sheets along with their scores. Answer sheets that contain comments and suggestions from researchers are distributed to students, so they can evaluate their shortcomings. After going through the result communication stage for feedback, students are expected to be able to find out the deficiencies made during the implementation of formative tests and self-assessments so that students can improve their learning quality. In general, the result communicating stage for feedback was done well.

The utilization stage of the results of the self-assessment has the aim of knowing whether the self-assessment can be used as feedback for students on the implementation of the formative test. Based on the results of the questionnaire, as many as $92.60 \%$ or 25 students felt that the self-assessment on the formative test of salt hydrolysis could be used as feedback. The implementation of this self-assessment is expected to be able to train honesty, increase students' 
self-confidence in solving questions, and provide motivation to improve the quality of learning.

\section{The Ability of Students to Conducting Self-Assessment}

The ability of students to conducting self-assessment describes the ability of students to assess the results of their own work. The better the ability of students in conducting assessments, the better the ability of students to conduct self-assessment of the formative test results (Wanner, T. \& Palmer, E., 2018). Data comparison of assessments by students with assessments by researchers is shown in Figure 5.

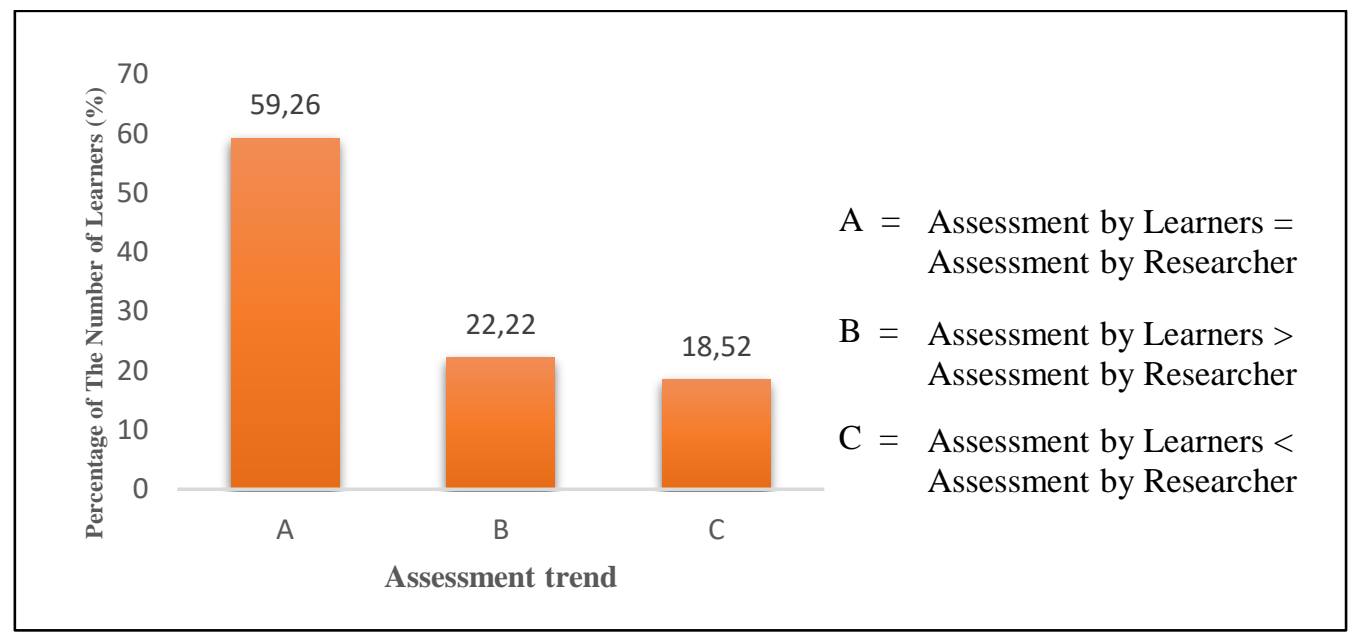

Figure 5. Percentage Comparison of Salt Hydrolysis Formative Test Assessment by Students and Researcher

According to Arikunto (Arikunto, S., 2013), the ability of students is divided into three categories, namely the "good", "enough", and "less" category. The following are categories of students' abilities in conducting self-assessments shown in Figure 6.

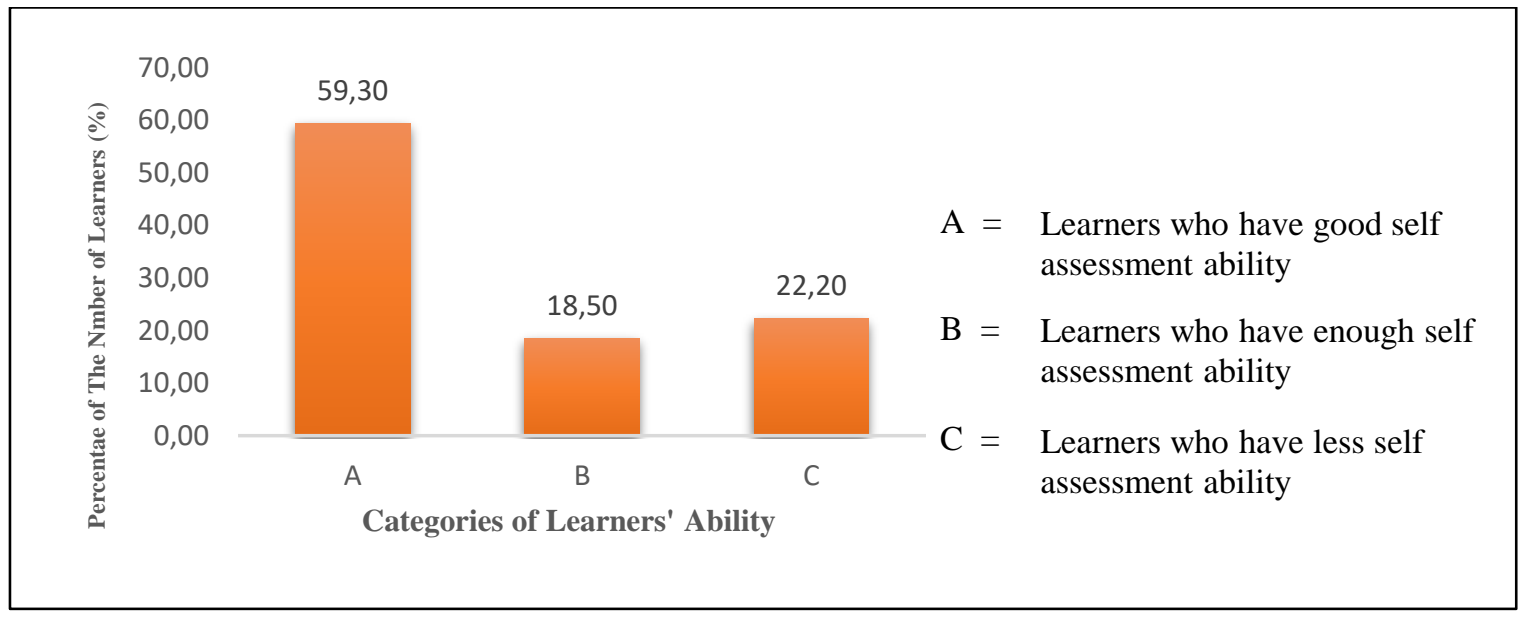

Figure 6. Percentage of Students' Ability Categories in Conducting Self-Assessment on Formative Test of Salt Hydrolysis

Thabiea : Journal of Natural Science Teaching 
Factors that cause differences in assessments carried out by students include students who are not careful in checking the answers to the formative test results that are checked using a self-assessment rubric. Another contributing factor is that students do not understand the selfassessment rubric and also feel less confident in assessing the results of their own work, which causes students to hesitate when giving scores and they worry that the score given is too large or even too small (Siswaningsih, W. et al., 2013).

\section{The Self-Assessment Capability on Formative Test of Salt Hydrolysis to be Used Feedback}

Self-assessment is used by students to monitor their learning process and can provide appropriate feedback (Shatri, Z. G. \& Zabeli, N., 2018). Therefore, the capability of selfassessment on the formative test of salt hydrolysis needs to be known so that students can get appropriate feedback. The capability of self-assessment on the formative test of salt hydrolysis to be used as a feedback, was known through questionnaires and interviews with students. The results of questionnaires and interviews with students related to self-assessment on the formative test of salt hydrolysis can be used as feedback shown in Figure 7.

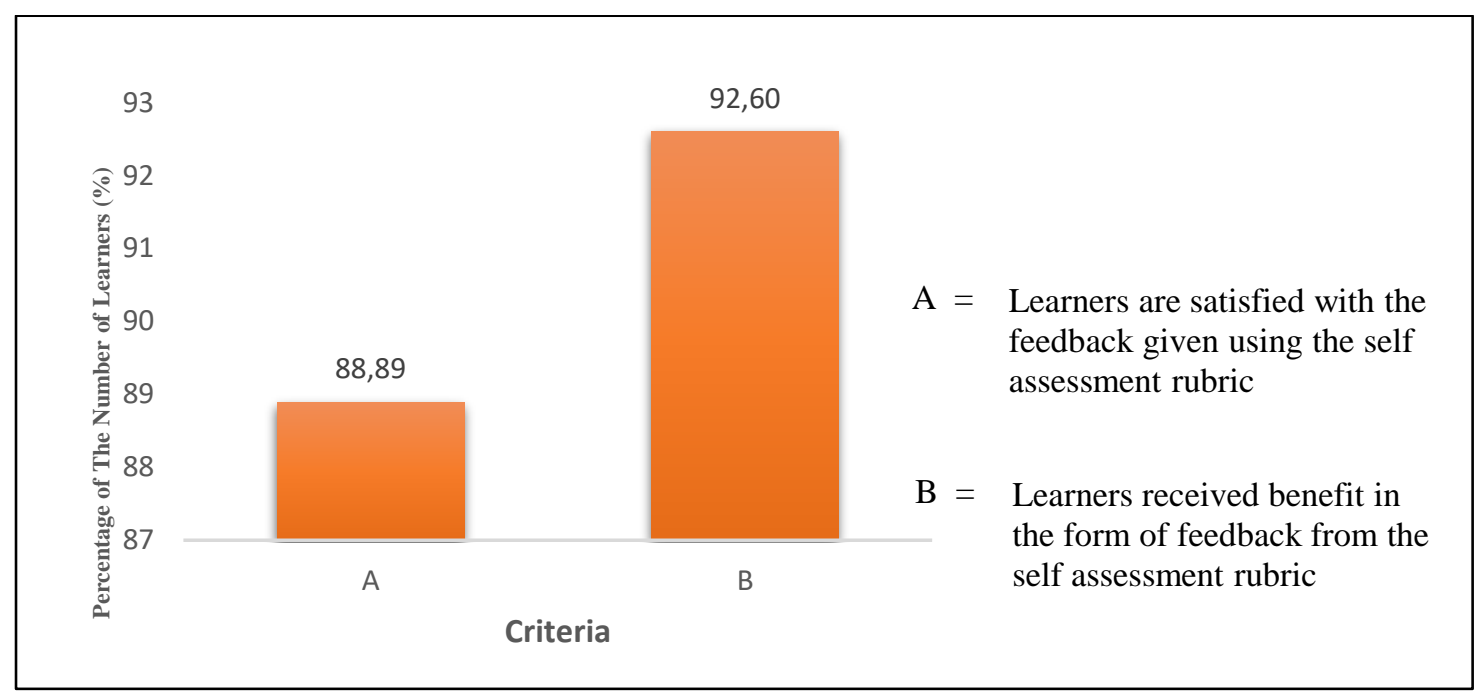

Figure 7. Percentage of Students Questionnaire and Interview Results for The Capability Self-Assessment on The Formative Test of Salt Hydrolysis to be Used Feedback

The average result of self-assessment capability on the formative salt hydrolysis test to be used as feedback based on the two criteria is $90.75 \%$. According to Riduwan (Riduwan, 2010), the percentage of questionnaire data results and learner interviews from the two criteria is very strong, so it can be said that self-assessment can help educators in providing feedback to students. Furtak (Furtak, E. M., 2009) mention that the feedback provided by educators to students, by providing information about what students have done, it will help provide a way for them to achieve learning goals. The feedback is one of the requirements for student-centered learning success and it's very important in learning because it can help students develop their abilities (Bedford, S. \& Legg, S., 2007). 


\section{Conclusion}

Implementation of self-assessment conducted through six stages, with the category of each phase of the motivation stage of students and the self-assessment training stage with very well category, the implementation stage of the formative test using feedback clue with well category, the implementation stage of self-assessment with very well category, the result communication stage for feedback (ideal criteria implemented), and the utilization stage of the result with very well category. The implementation of self-assessment obtained $59.30 \%$ of students were able to conduct self-assessment well, $18.50 \%$ of students were able to conduct self-assessment quite well, and $22.20 \%$ of students were less than good at conducting selfassessment. 88.89\% of students are satisfied with the feedback given by using the selfassessment rubric and $92.60 \%$ of students received a benefit from feedback from the selfassessment rubric. It shows that self-assessment can help educators give feedback to students.

\section{Acknowledgment}

This work was supported by the Annual Work Plan and Budget of the Institute for Research and Community Service, Indonesian Education University 2020 (RKAT LPPM UPI 2020) Number: 819 /UN40.D/PT/2020 to support the improvement of the quality of lecturer performance through competitive grants in the fields, research, and community service.

\section{References}

Aeniah, R. (2012). Analisis Keterampilan Berpikir Kritis Siswa Kelas XI pada Pembelajaran Hidrolisis Garam Menggunakan Model Problem Solving. Fakultas Pendidikan Matematika dan Ilmu Pengetahuan Alam Universitas Pendidikan Indonesia.

Arifin, Z. (2017). Evaluasi Pembelajaran. Remaja Rosdakarya.

Arikunto, S. (2013). Dasar-Dasar Evaluasi Pendidikan (Revisi). Bumi Aksara.

Bedford, S., \& Legg, S. (2007). Formative peer and self feedback as a catalyst for change within science teaching. Chemistry Education Research and Practice, 8(1), 80-92. https://doi.org/10.1039/B6RP90022D

Furtak, E. M. (2009). Formative Assessment for Secondary Science Teacher (J. Haenel, Ed.). Corwin.

Kusminto, \& Joko, B. P. (2013). Analisis Penilaian Kinerja dengan Teknik Self Assessment Sebagai Evaluasi Kerja Mahasiswa pada Praktikum Fisika Dasar II Tadris Fisika IAIN Walisongo Semarang. Fakultas Sains Dan Teknologi, 3(2), 1-28.

Looney, A., Cumming, J., van Der Kleij, F., \& Harris, K. (2018). Reconceptualising the role of teachers as assessors: Teacher assessment identity. Assessment in Education: Principles, Policy and Practice, 25(5), 442-467. https://doi.org/10.1080/0969594X.2016.1268090

Orsmond, P., \& Merry, S. (2011). Feedback alignment: Effective and ineffective links between tutors' and students' understanding of coursework feedback. Assessment and Evaluation in Higher Education, 36(2), 125-136. https://doi.org/10.1080/02602930903201651

Orsmond, P., \& Merry, S. (2013). The Importance of Self-Assessment in Students' Use of Tutors' Feedback: A Qualitative Study of High and Non-High Achieving Biology 
Undergraduates. Assessment and Evaluation in Higher Education, 38(6), 737-753. https://doi.org/10.1080/02602938.2012.697868

Riduwan. (2010). Dasar-Dasar Statistika. Alfabeta.

Shatri, Z. G., \& Zabeli, N. (2018). Perceptions of students and teachers about the forms and student self-assessment activities in the classroom during the formative assessment. Journal of Social Studies Education Research, 9(2), 28-46. https://doi.org/10.17499/jsser.51331

Siswaningsih, W., Dwiyanti, G., \& Gumilar, C. (2013). Penerapan Peer Assessment dan Self Assessment pada Tes Formatif Hidrokarbon untuk Feedback Siswa SMA Kelas X Jurusan Pendidikan Kimia FPMIPA Universitas Pendidikan Indonesia Perubahan Paradigma Pendidik. Jurnal Pengajaran MIPA, 18, 107-115.

Thawabieh A. M. (2017). A Comparison between Students' Self-Assessment and Teachers' Assessment. Journal of Curriculum and Teaching, 6(1), 14. https://doi.org/ 10.5430/jct.v6n1p14

Udoukpong, B. E, \& Okon, C. P. (2012). Perception of Formative Evaluation Practices and Students' Academic Performance In Junior Secondary Certificate Examination in Social Studies. International Journal of Business and Social Science, 3(15), 204-212.

Wanner, T., \& Palmer, E. (2018). Formative self-and peer assessment for improved student learning: The crucial factors of design, teacher participation and feedback. Assessment and Evaluation in Higher Education, 43(7), 1032-1047. https://doi.org/10.1080/02602938.2018.1427698

Wanner, T., \& Palmer, E. (2018). Formative self-and peer assessment for improved student learning: The crucial factors of design, teacher participation and feedback. Assessment and Evaluation in Higher Education, 43(7), 1032-1047. https://doi.org/10.1080/02602938.2018.1427698

Yan, Z., Brown, G. T. L., Lee, J. C. K., \& Qiu, X. L. (2020). Student self-assessment: Why do they do it? Educational Psychology, 40(4), 509-532. https://doi.org/10.1080/01443410.2019.1672038 